\title{
Did alien ants initiate a population explosion of a coccoid plant pest on an islet in the Coral Sea?
}

\author{
Penelope Greenslade
}

Received: 14 September 2009/Accepted: 14 January 2010/Published online: 29 January 2010

(C) Springer Science+Business Media B.V. 2010

\begin{abstract}
The composition of the ant fauna of a Coral Sea islet, North East Herald Cay, is reported for several years from 1995 to 2007. A major change in composition was first noted in 2007 but probably occurred earlier. Tetramorium lanuginosum, present in 1997 and in previous years, was not found in 2007. Instead, Tetramorium bicarinatum, recorded for the first time in 2006, was abundant in 2007. This change, together with drier conditions, may have initiated a population explosion of a pest coccoid that caused serious damage to the tree, Pisonia grandis. Tetramorium bicarinatum also reduced the abundance of surface-active arthropods compared to their abundance when it was absent. Ants and other invertebrates on three other islets in the Coral Sea are also documented for 2007 and support the dominance effects of T. bicarinatums.
\end{abstract}

Keywords Tetramorium bicarinatum - Pisonia grandis . Pulvinaria urbicola . Herald Island group . Coringa/Magdelaine Island group

Addendum to: Climate variability, biological control and an insect pest outbreak on Australia's Coral Sea islets: lessons for invertebrate conservation. Journal of Insect Conservation 12: 333-342.

P. Greenslade $(\square)$

Environmental Management, School of Science and

Engineering, University of Ballarat, Ballarat,

VIC 3350, Australia

e-mail: Pgreenslade@staff.ballarat.edu.au

P. Greenslade

School of Biology, Australian National University,

Acton, Canberra, ACT 0200, Australia

\section{Introduction}

Greenslade (2008) provided a possible explanation for why a scale insect, Pulvinaria urbicola Cockerell and a species of attendant ant, Tetramorium bicarinatum (Nylander), underwent a sudden population explosion on North East Herald Cay (NEHC) in the Coral Sea in the 2001, thereby causing serious damage to Pisonia grandis, a tree important as a nesting site for sea birds. It was suggested that climate variability was likely to be a contributing factor. Rising sea surface temperatures were likely to have reduced prey available for nesting sea birds, and so lowered the numbers of birds nesting. With fewer nesting birds, soils received less nitrogen limiting nutrients available to Pisonia trees. This, together with lower rainfall, particularly in winter, in several years in the 1990s, would have put Pisonia trees under stress making them more vulnerable to attack by herbivores.

It is now possible to compare species composition of Formicidae on NEHC over 12 years from 1995 and also compare the ant fauna of NEHC in 2007 with that of three other islets in the Coringa Herald group, Coringa, Magdelaine and South East Herald, trapped in the same year. The new data suggest an additional reason for the pest population explosion.

\section{Sites and methods}

Data on ant species present on NEHC were collected using a range of methods in years 1994/1995, 1997 as well as from 2001 to 2007 (Greenslade and Farrow 2009). Collections were also made in 2007 on South West Herald Cay (SWHC), using the same methods and from pitfalls only on Coringa and Magdelaine Cays also in 2007. Details of 
Table 1 Comparison of absolute numbers and relative abundance of ant species collected from pitfalls (PF), yellow pans (YP) and leaf litter and soil samples (LLS) on North East Herald Cay in three different years

\begin{tabular}{llllll}
\hline Year & $\begin{array}{l}\text { Method of } \\
\text { collection }\end{array}$ & $\begin{array}{l}\text { Tetramorium } \\
\text { lanuginosum }\end{array}$ & $\begin{array}{l}\text { Tetramorium } \\
\text { bicarinatum }\end{array}$ & $\begin{array}{l}\text { Cardiocondyla } \\
\text { sp. cf. nuda }\end{array}$ & $\begin{array}{l}\text { Monomorium } \\
\text { pharaonsis }\end{array}$ \\
\hline $1995 / 1996$ & PF, LLS & $149(48 \%)$ & 0 & $40(12 \%)$ & $127(40 \%)$ \\
1997 & PF, YP, LLS & $44(31 \%)$ & 0 & $47(34 \%)$ & $49(35 \%)$ \\
2007 & PF, YP, LLS & 0 & $5059(99.7 \%)$ & $17(0.3 \%)$ & 0 \\
\hline
\end{tabular}

Trapping methods in 1997 and 2007 were identical

collections and all results are given in Greenslade and Farrow (2009). Collections were limited for practical reasons relating to difficulties with access to sites.

\section{Results}

Up to and including 1997, the ant fauna on NEHC consisted of three species in approximately equal numbers, Monomorium pharaonsis (Linnaeus), Tetramorium lanuginosum Mayr and Cardiocondyla sp. cf. nuda (Mayr). In 2007 M. pharaonsis was not trapped and $C$. sp. cf. nuda was only caught in extremely low numbers while another Tetramorium species, $T$. bicarinatum, not caught in earlier years, was present in high numbers (Table 1).

Tetramorium bicarinatum was also the only Tetramorium species present in 2007 on the neighbouring South West Herald (SWH), only seven km away, but no collections had been made on this island in previous years so comparisons over time were not possible.

There were also differences in ant species composition and/or abundance between the two other Coral Sea islet groups, Coringa and Magdelaine and the Heralds (Fig. 1) in 2007. On Coringa and Magdelaine, 75 and $125 \mathrm{~km}$ away, respectively, the dominant species of Tetramorium is the same species, T. lanuginosum, as was found on NEHC in 1997 and earlier.

The change in the dominant ant species on NEHC was accompanied by large changes in abundance of other ground invertebrates. A comparison of pitfall collections

Table 2 Total numbers and relative abundance of ants compared to other invertebrates trapped in pitfalls in the Coringa/Herald islets in various years

\begin{tabular}{lrcc}
\hline Year & Totals & Formicidae & $\begin{array}{l}\text { Invertebrates } \\
\text { excluding Formicidae }\end{array}$ \\
\hline 1997 NEHC & 252 & $95(37 \%)$ & $157(62 \%)$ \\
$2007 \mathrm{NEHC}+$ & 5,730 & $4,095(71 \%)$ & $1,635(28 \%)$ \\
2007 SWH+ & 1,804 & $1,469(81 \%)$ & $335(18 \%)$ \\
2007 Magdelaine & 2,064 & $148(7 \%)$ & $1,916(93 \%)$ \\
2007 Coringa & 304 & $96(31 \%)$ & $208(68 \%)$ \\
\hline
\end{tabular}

Trapping method was identical on all four islands made in 2007 on the four islands shows differences in numbers of invertebrate trapped between islands with T. bicarinatum and those without (Table 2). Coringa and Magdelaine, where T. bicarinatum was absent, are more similar to each other than to NEHC and SWHC where $T$. bicarinatum was present. When T. bicarinatum is absent, ants represent less than $40 \%$ of total invertebrate fauna trapped, but when $T$. bicarinatum is present, ants represent $70 \%$ or more of total fauna trapped.

\section{Discussion}

Donaldson (1995) first noted P. urbicola in low numbers on NEHC when Pisonia was not being conspicuously damaged. By 2001, the coccoid was in high numbers and causing serious damage to the trees (Smith and Papacek 2001). These authors identified the attendance ant as Tetramorium sp. but it was not identified to species level. As the data presented here shows, a major change in composition of the ant fauna on North East Herald (NEHC) occurred between 1997 and 2006, ${ }^{1}$ the year when the first specimens on $T$. bicarinatum were reliably identified to species, exemplified by the dominance of $T$. bicarinatum. It was so dominant on NEHC and SWHC that it resulted in three other ant species becoming either absent or present in very low numbers and it suppressed numbers of other ground invertebrates. A contrasting situation was present on Coringa and Magdelaine in 2007 where T. lanuginosum is not dominant and three species of ants are present as was found on NEHC in 1997 and earlier. These differences are not related to vegetational differences between the islands as Pisonia occurs on NEHC and Magdelaine but not on SWHC or Coringa. Trees were not experiencing damage from P. urbicola on Magdelaine although the coccoid is present there in low numbers. The results must be qualified because collections were limited spatially and temporarily, and only pitfalls were used to compare faunas between the four islets. The four islands were of a similar size, age and structure and vegetation was similar on all four except for

\footnotetext{
${ }^{1}$ Specimens identified as T. bicarinatum, in the Queensland Museum collected in May 2006 from NEHC, leg. C. Freebairn.
} 


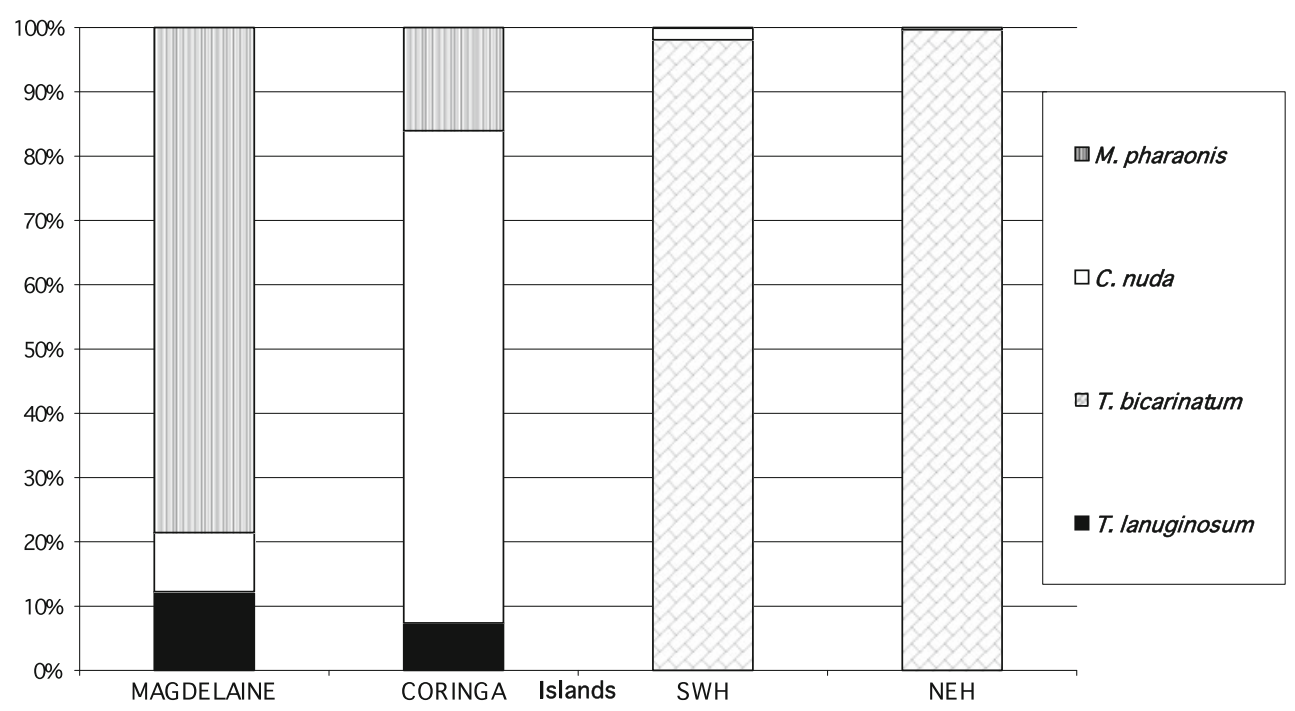

Fig. 1 Proportion of each ant species present in 2007 in pitall collections on the four islands

the presence or absence of Pisonia, so that they could be considered as true replicates.

The cause of the coccoid population explosion therefore could have been primarily caused by the arrival of the invasive ant but it still remains likely that climate variability resulted in increased vulnerability of Pisonia trees to herbivore attack. Briese (1982) documented a similar phenomenon in a chenopodiaceous shrubland in a period of exceptionally low rainfall when a related coccoid, Pulvinaria maskelli Olliff, experienced a population explosion causing extensive damage to shrubs at the same time as there was an increase in abundance and number of nest entrances of an attendant ant, Iridomyrmex sp. Populations fell when rainfall again increased.

A biological survey was undertaken on NEHC in June 1997 when 20 people camped on the island for 2 weeks taking ashore much equipment and fresh food (Anon 2001). It is possible that it was at this time that T. bicarinatum was introduced to NEHC. Another possible pathway was via timber taken to the island and stored there for construction purposes. Tetramorium bicarinatum normally nests in timber and soil. It is suggested that there is a need for strict quarantine controls to be applied, particularly for Magdelaine Island, with ongoing monitoring for ants and inspections of shipping before departure to the islands. Off-loading on islands of fresh food, timber or any soil-contaminated equipment that could harbour nests of ants, should not be permitted. Although T. bicarinatum is not considered an aggressive invader on the Australian mainland, when colonising islands with impoverished faunas and floras, different behaviour is likely.

Acknowledgments Thanks are due to the Department of Environment, Heritage and Water Resources for part funding, and for fieldwork on Magdelaine and Coringa, to colleagues, Robert Taylor and Brian Heterick for confirmation of ant identifications and to referees for suggestions as to improving the paper.

\section{References}

Anon (2001) Herald Cays scientific study report. Geography monograph series No. 6. Royal Geographic Society of Queensland. Brisbane, Qld. p 168

Briese DT (1982) Damage to saltbush by the coccid Pulvinaria maskelli Olliff, and the role played by an attendant ant. J Aust ent Soc 21:293-294

Donaldson S (1995) Preliminary report on April 1994 Coral Sea national nature reserve patrol. Unpublished report to the Australian National Parks and Wildlife Service

Greenslade P (2008) Climate variability, biological control and an insect pest outbreak on Australia's Coral Sea islets: lessons for invertebrate conservation. J Insect Conserv 12:333-342

Greenslade P, Farrow R (2009) Coringa-Herald national nature reserve-identification of invertebrates collected on the 2007 invertebrate survey for The Department of the Environment, Water, Heritage and the Arts, June 2008. http://www.environment. gov.au/coasts/mpa/publications/coringa-herald-terrestrial-inverte brate-survey.html. Accessed July 2009

Smith D, Papacek D (2001) Report on the levels of the scale insect Pulvinaria urbicola and its natural enemies on Pisonia grandis in the Coringa-Herald national nature reserve 16-23 March 2001. Report to Environment Australia. http://www.environment. gov.au/coasts/mpa/publications/pubs/coringa-pest-scale-2.pdf. Accessed Aug 2009 